\title{
Elemental Sulfur Recommendations for Sugarcane on Florida Organic Soils ${ }^{1}$
}

\author{
J. Mabry McCray ${ }^{2}$
}

\section{Introduction}

This document is intended primarily for Florida sugarcane growers but may also be useful to researchers and others interested in sugarcane nutrition. It presents revised elemental sulfur recommendations for sugarcane grown on Florida organic soils along with supporting information. Micronutrient deficiencies can be important limiting factors in alkaline soils, with most micronutrients becoming less available for plant uptake as soil $\mathrm{pH}$ increases. In the Florida Everglades Agricultural Area (EAA), the organic soils (Histosols) are subsiding because of microbial oxidation, resulting in decreasing soil depth to the underlying limestone. The $\mathrm{pH}$ in these soils has increased in recent years as tillage operations incorporate more calcium carbonate into the topsoil. Additionally, carbonates move into the soil surface as part of subsurface seepage irrigation.

The micronutrient that is often most limiting for sugarcane production on high $\mathrm{pH}$ organic soils in the EAA is manganese $(\mathrm{Mn})$. A survey of Florida commercial sugarcane fields in 2004-2006 determined that $36 \%$ of fields on organic soil were limited in production by insufficient manganese. Current recommendations are to apply $5 \mathrm{lb} \mathrm{Mn/acre} \mathrm{at}$ planting for sugarcane grown on organic soils with $\mathrm{pH}>$ 6.0 (Rice, Gilbert, and McCray 2010). However, with soil $\mathrm{pH}>7.0$, most of any added manganese quickly becomes unavailable. Previous research (Allison 1931; Forsee 1950) determined that elemental sulfur application could be used to improve availability of micronutrients and phosphorus to the crop but is not necessary to correct any nutritional sulfur deficiency in EAA organic soils. Elemental sulfur is an effective soil acidifier as the sulfur is oxidized by soil microorganisms to form sulfuric acid, changing elemental $\mathrm{S}$ to the oxidized sulfate $\left(\mathrm{SO}_{4}^{2-}\right)$ form. It is important to emphasize that adding sulfate forms of sulfur to the soil does not change soil $\mathrm{pH}$ because the sulfate is already oxidized. There are additional acidifying agents such as aluminum sulfate, iron sulfate, or ammonium sulfate. However, these materials lower soil $\mathrm{pH}$ through the reactions of the aluminum, iron, and ammonium, respectively, and not through acidification from sulfate.

Sugarcane growers have used elemental sulfur applications in the EAA for many years to increase crop micronutrient availability. Applications have generally been banded in the furrow at planting because of the extremely high rates that would be required for broadcast applications. This is because of the high buffering capacity of the large amounts of calcium carbonate in alkaline organic soils that resist changes in $\mathrm{pH}$. Banded sulfur applications in the furrow concentrate the zone of $\mathrm{pH}$ reduction in the sugarcane row so there is maximum, cost-effective benefit to the crop. Granular elemental sulfur has been used by growers in recent years because of better handling and blending properties compared to those of powdered sulfur.

Previous UF/IFAS recommendations have suggested elemental sulfur applications of $500 \mathrm{lb}$ S/acre for sugarcane grown on organic soils with $\mathrm{pH}>6.6$ (Rice, Gilbert, and

1. This document is SS-AGR-429, one of a series of the Agronomy Department, UF/IFAS Extension. Original publication date February 2019. Visit the EDIS website at https://edis.ifas.ufl.edu for the currently supported version of this publication.

2. J. Mabry McCray, scientist, Agronomy Department, UF/IFAS Everglades Research and Education Center, Belle Glade, FL 33430.

The Institute of Food and Agricultural Sciences (IFAS) is an Equal Opportunity Institution authorized to provide research, educational information and other services only to individuals and institutions that function with non-discrimination with respect to race, creed, color, religion, age, disability, sex, sexual orientation, marital status, national origin, political opinions or affiliations. For more information on obtaining other UF/IFAS Extension publications, contact your county's UF/IFAS Extension office. 
McCray 2010), which was a slight change from the break point of $\mathrm{pH} \geq 6.5$ in recommendations from 1979 (Gascho and Kidder 1979). Growers have not generally used this 500 $\mathrm{lb}$ S/acre rate through this entire $\mathrm{pH}$ range because they have not determined this to be cost-effective. A series of trials was conducted to evaluate sugarcane yield response to elemental sulfur on high $\mathrm{pH}$ organic soils in the EAA and to determine more effective recommendations. Results of this study have been used to revise elemental sulfur recommendations.

\section{Sugarcane Yield Response to Elemental Sulfur Application}

Two trials examining sugarcane yield response to elemental sulfur application were conducted from 1996 to 1999 (Sites 1 and 2, Table 1) (McCray and Rice 2013). Four additional trials were conducted from 2006 to 2012 (Sites 3-6, Table

1) (McCray, Ji, and Crusciol 2018). All soils in the trials were muck soils except Site 2, which was a sandy muck. All elemental sulfur applications in these trials were made in the furrow at planting. All sulfur was applied as $90 \%$ sulfur or as STM5 (80\% sulfur with 5\% manganese within each granule). Different formulations of STM5 were also compared at Sites 1 and 2. In these experiments, STM5-A was non-granular material made by mixing granular material with fine material, and STM5-B and STM5-C were granular materials from different manufacturers. The non-granular material (STM5-A) is no longer made because it was more difficult to manufacture, and the different size particles segregated during transport and application.

Elemental sulfur application (400 lb S/acre) significantly increased tons sugar/acre (TSA) for the plant cane and first ratoon crops at Site 1 (Table 2). At Site 2, there were significant increases in TSA with elemental S application in the plant cane crop; however, differences were not significant in the first ratoon crop. When plant cane data for Sites 1 and 2 were combined, there was a strong inverse relationship between relative sugar yield and soil $\mathrm{pH}$ (Figure 1). There was a decrease in relative sugar yield with $\mathrm{pH}>7.1$, with relative sugar yield reduced to less than 0.80 with $\mathrm{pH} \geq 7.5$.

At Sites 3, 4, and 5 there were no significant increases in TSA with elemental sulfur application (Table 3). There were differences in TSA between treatments at Site 3, but no evidence of a yield response to sulfur application. At Site 6 there was no TSA response to elemental sulfur application (Table 4). Soil pH was consistently reduced in the plant row by sulfur application at all trials, although the amount of $\mathrm{pH}$ reduction varied by location and sulfur rate. This was likely due to inherent differences in soil buffering at the different sites.

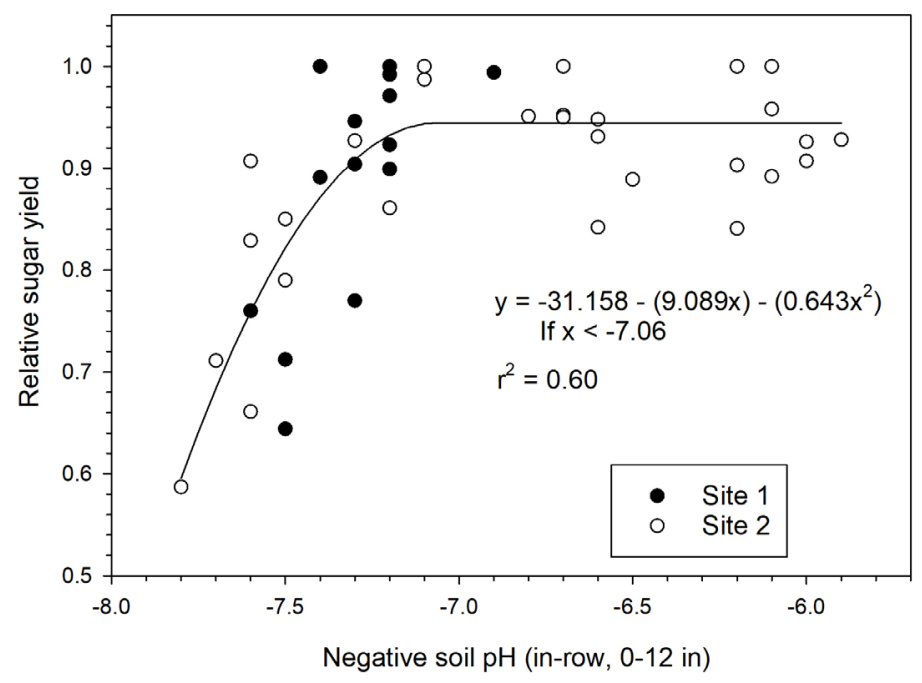

Figure 1. Relationship between plant cane relative sugar yield and negative soil $\mathrm{pH}$ (or $\log \mathrm{H}^{+}$ion concentration) for all treatments at Sites 1 and 2 . Negative $\mathrm{pH}$ was used in developing the model so that yield increases to the right on the $\mathrm{x}$-axis.

Credits: McCray and Rice (2013)

Sugarcane yield responses to elemental sulfur application can generally be explained by the initial soil $\mathrm{pH}$ at each location (Table 1; Figure 2). Lower relative sugar yield for plots with no sulfur application in Figure 2 is an indication of stronger yield response to elemental sulfur. There was no yield response to elemental sulfur application with initial mean $\mathrm{pH} \leq 7.1$, as indicated by the high relative sugar yield at Sites 3, 4, and 5 for zero $S$ treatments. There were significant yield responses at Sites 1 and 2 with initial mean $\mathrm{pH}$ of 7.5 and 7.2, and relative yields of 0.73 and 0.77 , respectively. The lack of a yield response at Site 6 with mean $\mathrm{pH} 7.2$ is an indication that there can be variable response at soil $\mathrm{pH}$ near the break point of 7.1 depending on differences in soil characteristics or possibly sugarcane cultivars. Leaf manganese concentration at Site $6(7 \mathrm{mg} / \mathrm{kg}$ for zero S plots) was well below the sufficiency range (20-100 mg Mn/ $\mathrm{kg}$ ) (McCray and Mylavarapu 2010), indicating that plant manganese uptake was limited at that location. Among all of the test location soils, the soil at Site 6 was the deepest (Table 1). Soil depth could influence sugarcane growth in relation to $\mathrm{pH}$ and available $\mathrm{Mn}$.

There were no significant differences in yield response between sources of granular elemental sulfur (Tables 2-4). However, STM5 has the advantage of having manganese within each sulfur granule and can increase manganese availability by lowering $\mathrm{pH}$ in the microenvironment where manganese is added to the soil. This does not suggest that STM5 should be used exclusively instead of $90 \% \mathrm{~S}$, but that some STM5 should perhaps be used in a fertilizer blend whenever elemental sulfur is applied. 


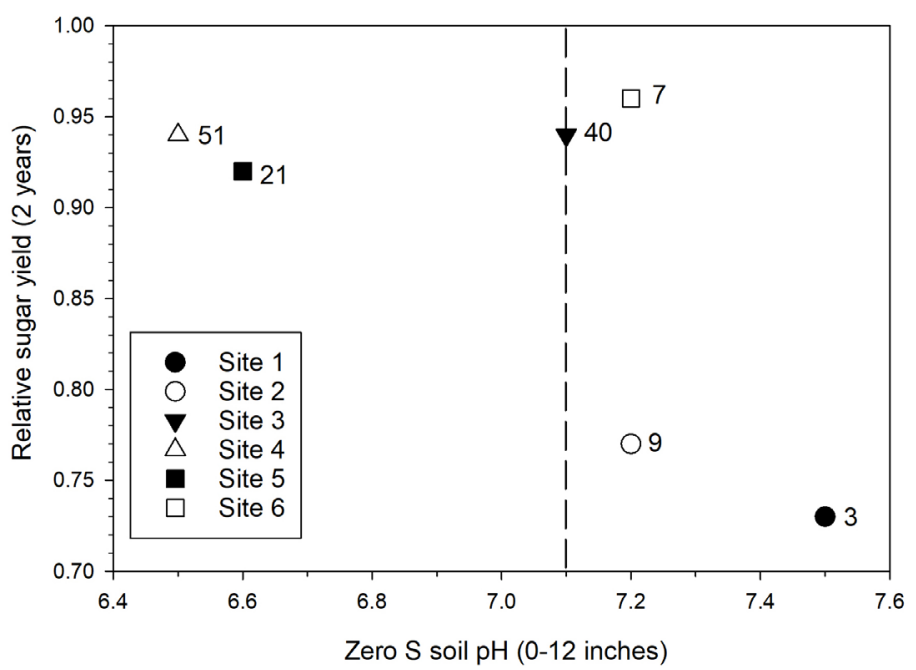

Figure 2. Graph of relative sugar yield (two-year cumulative plant cane and first ratoon) of the zero $\mathrm{S}$ treatment versus initial soil $\mathrm{pH}$ for all sulfur trials' sites. Mean July/August zero S leaf Mn concentration ( $\mathrm{mg} \mathrm{Mn} / \mathrm{kg}$ ) from the plant cane crop of each site is shown to the right of each symbol. The vertical line indicates the break point in the relationship of relative yield shown in Figure 1.

Credits: McCray, Ji, and Crusciol (2018)

\section{Revised Elemental Sulfur Recommendations}

Table 5 lists revised elemental sulfur recommendations for sugarcane grown on muck or sandy muck in Florida. These recommendations are for application in the furrow at planting. Applications of elemental sulfur to the soil surface are not as effective because the sulfur reacts at the point of placement and needs to be placed in the root zone to effectively lower soil $\mathrm{pH}$ for the crop. All $\mathrm{pH}$ measurements are based on a 1:2 soil/water volumetric ratio as determined by the UF/IFAS Soil Testing Laboratory. The highest recommendation (250-500 lb S/acre) is for $\mathrm{pH} \geq 7.5$. Substantial reduction in TSA was determined for individual plots at Sites 1 and 2 for $\mathrm{pH} \geq 7.5$. Also, at $\mathrm{pH} \geq 7.5$, leaf manganese concentration was less than sufficient for all individual plots in the study. A range of 250-500 lb S/acre allows flexibility for the degree of deficiency symptoms that have been observed in a field.

Recommended sulfur rates are decreased with $\mathrm{pH}<7.5$, with no $S$ recommended below $\mathrm{pH}$ 7.0. The $100 \mathrm{lb}$ S/acre rate is extended slightly below the $\mathrm{pH}$ break point of 7.1 in Figure 1 to allow for some variability in soil $\mathrm{pH}$. These elemental sulfur recommendations specify soil $\mathrm{pH}$ values at which manganese availability is reduced and a yield response is probable. Applying the first $100 \mathrm{lb}$ S/acre as STM5 to provide additional manganese with the sulfur is recommended. At higher sulfur rates, a blend of STM5 and $85 \%$ or $90 \%$ S can be used. This should lower the cost of the material.
Soil $\mathrm{pH}$ is often variable across a field, so variable rate application of elemental sulfur might be effective in many situations if a grower has the equipment and chooses this option. Ditch banks and field ends can frequently be higher in $\mathrm{pH}$ because of ditch cleaning and marl roads; therefore, separate sulfur applications in these areas may be beneficial. If visual symptoms of manganese deficiency manifest during the crop, growers can also make foliar manganese applications (5 lb Mn/acre/application) which can provide a short-term benefit to the crop. Pictures of deficiency symptoms are available at http://edis.ifas.ufl.edu/sc075 (McCray et al. 2013).

Leaf nutrient analysis can assist in planning future fertilizer applications. Instructions for collecting and preparing sugarcane leaf samples are available at http://edis.ifas.ufl. edu/sc076 (McCray et al. 2015).

\section{References}

Allison, R. V. 1931. "The importance of certain special elements in agriculture of south Florida." Proceedings of the Florida State Horticultural Society 44: 11-22.

Forsee, Jr., W. T. 1950. “The place of soil and tissue testing in evaluating fertility levels under Everglades conditions." Proceedings of the Soil Science Society of America 15: 297-299. http://doi.org/10.2136/ sssaj1951.036159950015000c0068x

Gascho, G. J. and G. Kidder. 1979. Responses to Phosphorus and Potassium and Fertilizer Recommendations for Sugarcane in South Florida. Bulletin 809. Gainesville: Florida Cooperative Extension Service.

McCray, J. M., I. V. Ezenwa, P. R. Newman, and R. W. Rice. 2015. Sugarcane Leaf Tissue Sample Preparation for Diagnostic Analysis. SS-AGR-259. Gainesville: University of Florida Institute of Food and Agricultural Sciences. http:// edis.ifas.ufl.edu/sc076

McCray, J. M., S. Ji, and C. Crusciol. 2018. "Influence of elemental sulfur on sugarcane yield on Histosols with near-neutral pH." Communications in Soil Science and Plant Analysis 49(1): 109-123. http://doi.org/10.1080/00103624.2 017.1421653

McCray, J. M. and R. Mylavarapu. 2010. Sugarcane Nutrient Management Using Leaf Analysis. SS-AGR-335. Gainesville: University of Florida Institute of Food and Agricultural Sciences. http://edis.ifas.ufl.edu/ag345 
McCray, J. M. and R. W. Rice. 2013. "Sugarcane yield response to elemental sulfur on high $\mathrm{pH}$ organic soils." Proceedings of the International Society of Sugar Cane Technologists 28: 280-287.

McCray, J. M., R. W. Rice, I. V. Ezenwa, T. A Lang, and L. Baucum. 2013. Sugarcane Plant Nutrient Diagnosis. SS-AGR-128. Gainesville: University of Florida Institute of Food and Agricultural Sciences. http://edis.ifas.ufl.edu/ sc075

Rice, R. W., R. A. Gilbert, and J. M. McCray. 2010. Nutritional Requirements for Florida Sugarcane. SS-AGR-228. Gainesville: University of Florida Institute of Food and Agricultural Sciences. http://edis.ifas.ufl.edu/sc028 
Table 1. Sugarcane cultivar, planting date, soil series, initial soil pH, and soil depth for each site in elemental sulfur studies on organic soils.

\begin{tabular}{|c|c|c|c|c|c|}
\hline Site & Cultivar & Plant Date & Soil Series & $\begin{array}{c}\text { Soil pH } \\
\text { (0-12 inches) }\end{array}$ & $\begin{array}{l}\text { Soil Depth (in) } \\
\text { mean (range) }\end{array}$ \\
\hline 1 & CL 69-886 & 28 Dec 1996 & Dania & 7.5 & $14(10-18)$ \\
\hline 2 & CL 77-797 & 21 Nov 1996 & Plantation & 7.2 & $29(28-30)$ \\
\hline 3 & CP 88-1762 & 6 Nov 2006 & Lauderhill & 7.1 & $21(16-36)$ \\
\hline 4 & CP 78-1628 & 2 Nov 2007 & Dania & 6.5 & $17(12-24)$ \\
\hline 5 & CP 89-2143 & 16 Nov 2007 & Dania & 6.6 & $19(10-30)$ \\
\hline 6 & CP 89-2143 & 2 Dec 2009 & Pahokee & 7.2 & $38(28-43)$ \\
\hline
\end{tabular}

Table 2. Effects of sulfur treatments on soil pH (in-row, 0-12 inch depth) following plant cane and tons sugar/acre for plant cane and first ratoon crops in elemental sulfur trials at Sites 1 and 2.

\begin{tabular}{|c|c|c|c|c|c|c|c|}
\hline \multirow[b]{2}{*}{$\begin{array}{l}\text { Sulfur } \\
\text { Source }\end{array}$} & \multirow[b]{2}{*}{ S Rate } & \multicolumn{3}{|c|}{ Site 1} & \multicolumn{3}{|c|}{ Site 2} \\
\hline & & pH & $\begin{array}{l}\text { Plant } \\
\text { Cane }\end{array}$ & $\begin{array}{c}\text { First } \\
\text { Ratoon }\end{array}$ & \multirow[t]{2}{*}{ pH } & $\begin{array}{l}\text { Plant } \\
\text { Cane }\end{array}$ & $\begin{array}{c}\text { First } \\
\text { Ratoon }\end{array}$ \\
\hline & & & \multicolumn{2}{|c|}{ tons sugar/acre } & & \multicolumn{2}{|c|}{ tons sugar/acre } \\
\hline None & 0 & 7.5 & 3.62 & 2.15 & 7.2 & 3.96 & 2.34 \\
\hline $90 \% \mathrm{~S}$ & 225 & & & & 7.1 & 4.43 & 2.46 \\
\hline $90 \% \mathrm{~S}$ & 450 & & & & 6.5 & 4.96 & 3.15 \\
\hline STM5-A & 200 & & & & 6.5 & 4.90 & 3.26 \\
\hline STM5-A & 400 & 7.2 & 4.84 & 3.06 & 6.8 & 4.77 & 3.02 \\
\hline STM5-B & 400 & 7.3 & 4.67 & 2.55 & & & \\
\hline STM5-C & 200 & & & & 6.9 & 4.63 & 2.80 \\
\hline STM5-C & 400 & 7.2 & 4.91 & 2.69 & 6.6 & 4.95 & 3.20 \\
\hline Significance & & * & $* * *$ & * & $* *$ & * & NS \\
\hline
\end{tabular}

Table 3. Effects of sulfur treatments on tons sugar/acre and soil pH (in-row, 0-6 inch depth) means for all crops in elemental sulfur trials at Sites 3, 4, and 5.

\begin{tabular}{|c|c|c|c|c|c|c|c|}
\hline \multirow[b]{2}{*}{ Sulfur Source } & \multirow[b]{2}{*}{ S Rate } & Site 3 & Site 4 & Site 5 & Site 3 & Site 4 & Site 5 \\
\hline & & \multicolumn{3}{|c|}{----Tons sugar/acre---- } & \multicolumn{3}{|c|}{--------Soil pH--------- } \\
\hline None & 0 & 6.79 & 5.27 & 5.85 & 7.35 & 6.51 & 6.35 \\
\hline $90 \% \mathrm{~S}$ & 80 & 6.56 & 5.58 & 6.43 & 7.22 & 6.39 & 6.64 \\
\hline $90 \% \mathrm{~S}$ & 200 & 6.21 & 5.31 & 6.16 & 7.11 & 6.22 & 6.34 \\
\hline $90 \% \mathrm{~S}$ & 400 & 6.56 & 5.45 & 6.52 & 7.01 & 6.22 & 5.92 \\
\hline STM5 & 80 & 6.56 & 5.63 & 6.12 & 7.20 & 6.35 & 6.59 \\
\hline STM5 & 200 & 6.74 & 5.45 & 6.25 & 7.02 & 6.29 & 6.25 \\
\hline STM5 & 400 & 7.14 & 5.22 & 6.43 & 6.93 & 6.13 & 6.11 \\
\hline Significance & & * & NS & NS & $* * *$ & $* * *$ & $* * *$ \\
\hline
\end{tabular}


Table 4. Effects of sulfur source and rate on tons sugar/acre and soil pH (in-row, 0-6 inch depth) means for all crops in the elemental sulfur trial at Site 6.

\begin{tabular}{|l|c|c|}
\hline S Source & Tons sugar/acre & Soil pH \\
\hline $90 \%$ S & 8.21 & 7.14 \\
\hline STM5 & 8.30 & NS \\
\hline Significance & & 7.12 \\
\hline & & \\
\hline S Rate (lb/acre) & 8.21 & 7.16 \\
\hline 0 & 8.30 & 7.13 \\
\hline 80 & 8.35 & 7.09 \\
\hline 200 & 8.30 & 7.08 \\
\hline 400 & $\mathrm{NS}$ & $* * *$ \\
\hline Significance & & \\
\hline$* * *$ Significant difference at the $99.9 \%$ confidence level. & & \\
\hline NS, No significant difference at the $95 \%$ confidence level. & & \\
\hline
\end{tabular}

Table 5. Elemental sulfur recommendations for sugarcane grown on organic soils (mucks or sandy mucks) in Florida. ${ }^{1}$

\begin{tabular}{|c|c|}
\hline Soil pH & $\begin{array}{l}\text { Elemental Sulfur Recommendation } \\
\text { (Ib S/acre banded in furrow) }\end{array}$ \\
\hline 7.0 & 100 \\
\hline 7.1 & 100 \\
\hline 7.2 & 150 \\
\hline 7.3 & 200 \\
\hline 7.4 & 200 \\
\hline$\geq 7.5$ & $250-500$ \\
\hline
\end{tabular}

